\title{
DECENTRALIZÁLT SZENNYVÍZTISZTÍTÁS SZEREPE A TELEPÜLÉSI VÍZGAZDÁLKODÁSBAN
}

\section{ROLE OF THE DECENTRALIZED WASTEWATER TREATMENT IN MUNICIPAL WATER MANAGEMENT}

\author{
CZAKÓ Levente; KARCHES Tamás \\ (ORCID: 0000-0001-7231-2626); (ORCID: 0000-0003-2347-3559) \\ levi.czako@gmail.com, Karches.Tamas@uni-nke.hu
}

\begin{abstract}
Absztrakt
A különböző szennyvízkibocsátások elvezetése, kezelése kiemelt fontosságú a közegészségügyi kockázatok elkerülése és a befogadó vízminőségének megóvása érdekében. A csatornahálózat kiépitésekor arra törekszünk, hogy a szennyvíz szállitását úgy végezzük, hogy abban biológiai folyamatok, iszaplerakódás ne induljon be. Az urbanizáció hatására a meglévő hálózatok túlterheltté válhatnak, a telepre a szennyvíz hosszabb úton érkezhet meg. A kiszolgált agglomeráció bővülése esetén szóba jöhetnek decentralizált szennyvízkezelő megoldások, melyek lehetnek a szennyvíz keletkezési helyénél létesített több kisebb kapacitású telep, kisebb lakóövezet, egy-két családot kiszolgáló egyedi kisberendezés és/vagy természetközeli (extenziv) szennyvíztisztítási rendszerek. A cikk célja ezen lehetöségek feltárása. A projekt az Európai Unió támogatásával, az Európai Szociális Alap (ESZA) társfinanszírozásával valósul meg (a támogatási szerződés száma: EFOP-3.6.1-162016-00025, projekt címe: A vízgazdálkodási felsőoktatás erősítése az intelligens szakosodás keretében)
\end{abstract}

Kulcsszavak: csatornázás, decentralizált szennyviztisztítás, egyedi szennyvízkezelés, extenziv szennyvíztisztítás, települési vízgazdálkodás

\begin{abstract}
Wastewater from various sources may cause public health risk and deteriorate the quality of the receiving water body, where the key factor is on the performance of the collection and treatment system. Design of a sewerage system shall support the transportation of sewage without an extensive biological activity and sludge deposition in the system. Due to urbanization the existing network could be overloaded, the residence time of the fluid is increased. The expansion of the collection system supports the spread of alternative decentralized solutions, such as multiple small capacity wastewater treatment plants (WWTPS) as well as package plants or individual systems including extensive systems. Goal of this study is to analyze the possible decentralized wastewater alternatives. This work has been undertaken as a part of a project founded by the EFOP3.6.1-16-2016-00025 aiming for the development of water management in Higher Education in the frame of intelligent specialization.
\end{abstract}

Keywords: decentralized wastewater treatment, extensive wastewater treatment, municipal water management, package plants, sewerage, 


\section{BEVEZETÉS}

Az ivóvízbiztonság megköveteli a városi vízciklus zárását, a fenntartható vízgazdálkodást [1,2], melynek fontos eleme a szennyvíztisztítás. A szennyvíz különféle vízhasználatok során keletkező, ásványi és szerves szennyeződéseket tartalmazó hulladékvíz, melyet gyakran a közüzemi csatornahálózaton külön vagy a csapadékvízzel együtt vezetnek el. A szennyvízkezelés célja a vízbázisvédelem, az egyes környezeti elemek megóvásával és nem pedig elsődlegesen kármentesítéssel [3].

Keletkezése alapján megkülönböztethetünk lakosságtól (kommunális), iparból és mezőgazdaságból származó szennyvizet. A szennyvízkezelő müveket a szennyvízösszegyüjtési terület alapján két nagy csoportba oszthatjuk: centralizált vagy decentralizált tisztítási rendszer. A centralizált szennyvíztisztítás során nagyobb településeken a keletkező szennyvizet összegyüjtjük és egy központi szennyvízkezelő telepen végezzük a tisztítását. Mivel kevés számú, de nagy kapacitású telepekröl beszélünk, ezért a szennyvíz összegyüjtéséhez hosszú csatornahálózat kiépítése szükséges.

A decentralizált szennyvízkezelés során több, kisebb telepen vagy egyedi megoldásokkal helyben kezeljük a szennyvizet, így nem szükséges hosszú csatornahálózat kiépítése. Hátránya lehet, hogy a lakosság közvetlen környezetében történik ennek megvalósítása, amely panaszokra adhat okot például az esetleges büzképződés miatt, és az üzemeltetéséhez sem áll rendelkezésre minden esetben képzett személyzet.

Mindkét esetben a szennyvíztisztítás alapfolyamatai azonosak, azonban a kialakításban és ehhez kapcsolódóan az üzemeltetésben lehetnek eltérések. A következő fejezetekben áttekintjük a szennyvíztisztítás fokozatait, a kezelt szennyvízminőségre meghatározott elöírásokat, a csatornázottság hátrányait, a decentralizált szennyvíztisztítás megoldási lehetőségeit.

\section{TISZTÍTÁSI IGÉNY ÉS ALAPFOLYAMATOK}

Magyarországon 2005. január 1-ig a 4/1984. (II. 7.) OVH rendelet [4] határértékei voltak érvényesek (1. táblázat) a tisztított szennyvizek meghatározó szennyező, illetőleg növényi tápanyag tartalmát (kémiai és biológiai oxigénigényét, $\mathrm{KOI}, \mathrm{BOI}_{5}$, lebegőanyag, nitrogénforma és az összes foszfor tartalmát) tekintve [5]. Az 28/2004. XII. 25. KvVM rendelet [6] új határértékek előírásán túl a hatóságoknak meghagyta a lehetőséget, hogy az elérni kívánt vízminőség érdekében szigoríthasson.

\begin{tabular}{|c|c|c|c|c|c|c|}
\hline \multirow{2}{*}{$\begin{array}{l}\text { Jellemzők } \\
\text { [mg/l-ben] }\end{array}$} & \multicolumn{6}{|c|}{ Területi kategóriák } \\
\hline & I & II & III & IV & V & VI \\
\hline KOI & 50 & 75 & 100 & 100 & 150 & 200 \\
\hline Lebegőanyag & 100 & 100 & 200 & 200 & 500 & 200 \\
\hline $\mathrm{NH}_{4}-\mathrm{N}$ & 2 & 5 & 30 & 10 & 30 & 10 \\
\hline $\mathrm{NO}_{3}-\mathrm{N}$ & 40 & 50 & 80 & 80 & - & 80 \\
\hline Összes P - TP & 1,8 & 2 & 2 & 2 & - & 2 \\
\hline
\end{tabular}

1. táblázat Az (4/1984. (II. 7.)) OVH rendelet határértékei a hazai befogadókra (saját szerkesztés [4] alapján) 
Az 1984. évi szabályozás a befogadók szennyezettsége, terheltsége és vízhozamait veszi figyelembe. Az új szabályozás ezzel szemben az üzemméret függvényében a határozza meg a határértékeket (2. táblázat), kiegészítve, hogy az egyes befogadók érzékenységének megfelelően regionális szigorításokat lehet alkalmazni. A határérték túllépéséért a telep szennyvízbírságot, a környezetbe kibocsátott szennyezőanyag mennyiség alapján pedig környezetterhelési díjat fizet.

\begin{tabular}{|c|c|c|c|}
\hline EU 271/1991 & \multicolumn{3}{|c|}{ Lakosegyenérték osztály (LE - 60 g BOI $/$ /fö nap) } \\
\hline Kategória & 1 & 2 & 3 \\
\hline Jellemzők (mg/l) & $<10$ ezer LE & 10 - 100 ezer LE & $>100$ ezer $\mathbf{L E}$ \\
\hline $\mathrm{BOI}_{5}$ & 25 & 25 & 25 \\
\hline KOI & 125 & 125 & 125 \\
\hline $\begin{array}{c}\text { Összes } \\
\text { lebegőanyag - TSS }\end{array}$ & 60 & 35 & 35 \\
\hline $\begin{array}{c}\text { Összes nitrogén - } \\
\text { TN }\end{array}$ & - & 15 & 10 \\
\hline Összes foszfor - TP & - & 2 & 1 \\
\hline
\end{tabular}

2. táblázat Az EU javaslat a kommunális szennyvíztisztítók kibocsátási határértékeire (saját szerkesztés [6] alapján)

A szennyvíztisztítás feladata, hogy a kezelt szennyvíz a befogadó víztest minőségét, számottevően ne befolyásolja; ne okozzon oxigénhiányt, ne segítse elő az eutrofizációs folyamatokat a különböző nitrogén- és foszforformák bejuttatásával, illetve ne veszélyeztesse a vízi szervezeteket [7]. A szennyvíz kezelésének folyamatai alapvetően fizikai, biológiai és kémiai müszaki müveleteken alapulnak, melyeket az alábbi fokozatokra tagolással különíthetünk el. [8]

- Első tisztítási fokozat célja a durva szennyeződések, felúszó vagy ülepedő anyagok eltávolítása, illetve ezen fokozatot követő mütárgyak tehermentesítése. Ezt a fokozatot elsősorban fizikai (mechanikai) eljárások, müveletek alkotják.

- Második tisztítási fokozat a szervesanyagot bontó, biológiai többlet nitrogén és többlet foszfor eltávolítást végző mikroorganizmusoknak megfelelő életkörülményt biztosítja, melyek bontják, ásványosítják, élö sejtanyaggá alakítják a szennyvíz szervesanyagát. A szervesanyagokat rendszerint aerob körülmények közt (oxigén jelenlétében) müködő mikroorganizmusok bontják, ezért levegőt vagy néhány esetben tiszta oxigént juttatnak a rendszerbe. Az intenzív biológiai tisztítás két legelterjedtebb technológiája az eleveniszapos és a biofilmes tisztítás. Az elöbbi lebegő biomasszát, utóbbi valamilyen hordozóhoz kötött biomasszát alkalmaz.

- Harmadik tisztítási fokozat a szennyvíz kémiai úton való kezelése, a kémiai foszforeltávolítás koaguláció és flokkuláció műveletei.

- Negyedik tisztítási fokozat a gyógyszermaradványok és egyéb mikroszennyező anyagok eltávolítását célozza meg, azonban kiépítése és üzemeltetése költséges. Az 
egyre szigorodó előírások olyan irányba mutatnak, hogy alkalmazása szükségessé válhat (pl. membrántechnológiával).

A különböző tisztítási módszerek vagy azok kombinációi a kommunális szennyvizek tisztítására olyan feltétellel jöhetnek szóba, hogy flexibilisek legyenek a gyakran változó vízmennyiség és vízminőség tekintetében, tolerálják az üzemzavarok vagy a hőmérséklet változásának, a zavaró vegyületek megjelenésének vagy ezek kombinációinak hatását, és alacsony fajlagos tisztítási költséggel rendelkezzenek. $[9,10]$

A biológiai módszerek között megkülönböztetnek természetközeli (extenzív) és mesterséges (intenzív) tisztítási módszereket. Előbbiek általában nagy térfogatokat, felületeket és hosszú tisztítási időt igényelnek. Az intenzív technológiák fajlagosan kevesebb hely- és időigényt jelentenek, éppen a tisztítást végző, nagyjából hasonló mikroorganizmusok nagymértékü koncentrálása eredményeként. Éppen ezért a gyakorlatban a nagyobb agglomerációkban általánosabb a mesterséges tisztítás alkalmazása. A szennyvizek 90-95\%-át az utóbbi megoldással tisztítják [5].

Azonban ezen megoldások külső energiabevitelét igénylik. A nagyvárosok, metropoliszok korlátozott hellyel rendelkeznek, illetve a területfejlesztési igények miatt a központosított rendszerekkel együtt jár a hosszú csatornahálózat kiépítésének igényével, mely számos üzemeltetési nehézséget okoz.

\section{CENTRALIZÁLT SZENNYVÍZTISZTIITÁS PROBLÉMÁl}

Ma már egy nagyobb szennyvíztiszttó telephez több $1000 \mathrm{~km}$-es csatornaszakasz is tartozhat és ennek fenntartása, üzemeltetése, karbantartása egyre nagyobb kihívást jelent a szakemberek számára. Az urbanizáció hatására a legtávolabbi szennyvízbebocsátási pontok egyre nagyobb távolságokra vannak a teleptől, amelynek következményeként a szennyvíz tartózkodási ideje is megnő a csatornahálózatban, ezzel egyre gyakrabban előforduló üzemeltetési problémákat okozva. Ez a hosszú csatornahálózatot, annak üzemeltetésének, fenntartásának nehézségét, a benne szállított szennyvizek minőségének romlását (anaerob környezet, berothadás, korrózió, zsírdugó-képződés) okozza.

Nagy problémát jelentenek az ételmaradékok, mert az elhasznált étolaj, zsiradék amint leérkezik a lefolyókon keresztül, azonnal megdermed, és rákövesedik a csatorna falára. Ezzel szűkíti a cső átmérőjét, és ezen a lerakódáson további szennyeződések (zsír, WC papír, nedves törlőkendők és más csatornahulladékok) tudnak megtapadni, így végül dugót, és karbantartás hiányában elöntést okoz. Ez történt a londoni Whitechapeltben, ahol 130 tonnás és 200 méter hosszú, monumentális zsírhegy (1. ábra) az egyik legnagyobb, amit valaha találtak, és a szakemberek szerint szennyvízáradással fenyegette a várost. [11]

A biológia vonatkozásában, a csatornarendszerben kialakuló redox körülmények meghatározó fontosságúak [12]. Aerob körülmények esetén a keletkező szag jelentéktelen, és a közegészségügyi és korróziós veszély is minimális. Ilyen csatornarendszerben a biológiailag könnyen bontható komponensek még a szennyvíztisztító telepre érkezés előtt biodegradálódhatnak, mely egyben iszapképződést jelent, és a csatornahálózatban lerakódhat. [13] 


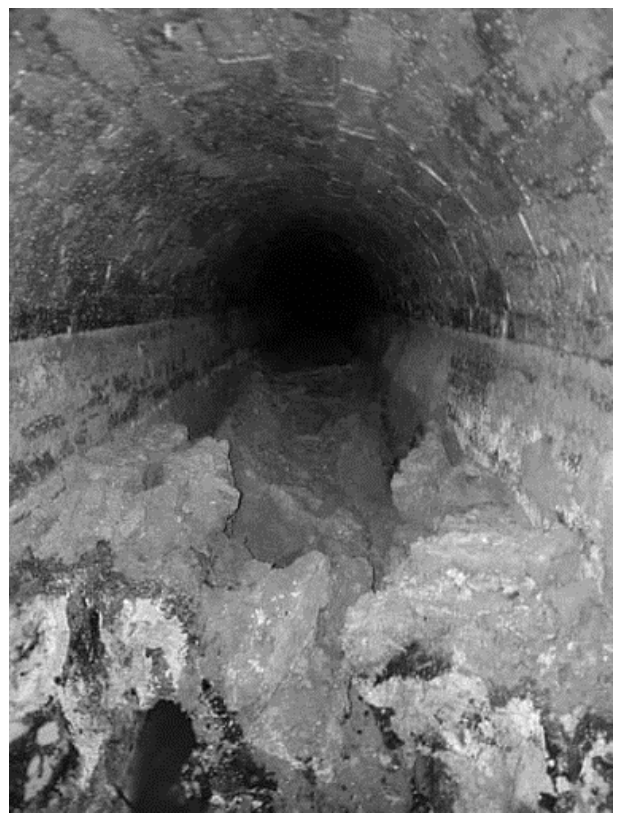

1. ábra A londoni „,csatornaszörny”, whitechapeli zsírhegy megkövült része a csatornafalon [11]

A szennyvízben végbemenő biológiai folyamatok nagyon összetettek, és többféle fázisban egyidejüleg következnek be: a folyadékban lebegö szilárd fázisok, a biofilmben, a fenéküledékben, valamint a közcsatorna csőfalának és gázterének az érintkezési felület. [14] $\mathrm{Az}$ anyagcserefolyamatok nemcsak a fázisokon belül, hanem az egyes fázisok között is lejátszódhatnak. Ami a lakosságot leginkább érzékenyen érinti az az anaerob folyamatok során képződő gázoknak a külső atmoszférába jutása, mely intenzív bủzhatásként jelentkezik. Az anyagforgalom kapcsolatrendszere a 2. ábrán látható.

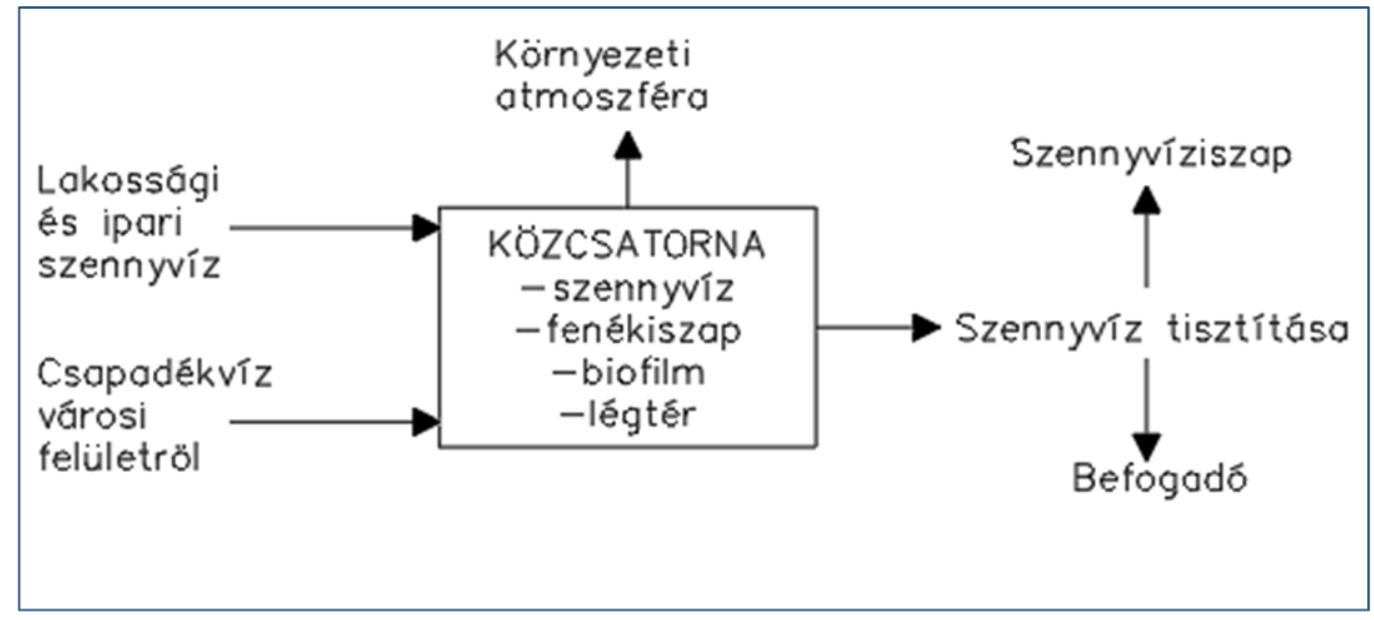

2. ábra Szennyvíz szállítása és átalakulása a lakossági csatornarendszerekben. (a szerző szerkesztése [15] alapján)

A közcsatornában a biológiai folyamatok többféle környezetben mennek végbe, szennyvízben a szennyezőkomponensek, és a mikroorganizmusok időben és térben eltérő széles skálája van jelen. A mikrobiológiai folyamatok egyidejüleg a különbözö fázisokban (szuszpendált vizes, biofilm, üledék és a gáz fázissal érintkező csőfal felület) játszódnak le. A mikrobiológiai folyamatok előrehaladása egyidejüleg a különböző fázisok kapcsolatával valósul meg, miközben fázisonként is gyakran változó aerob és anaerob körülmények alakulnak ki. A tápanyagok (mind az elektron donor szerves anyag, mind az elektron akceptorok - oxigén, 
nitrát), valamint a mikroorganizmusok kicserélődése és ezek között a fázisok között folyamatos. [15]

\section{DECENTRALIZÁLT SZENNYVÍZTISZTÍTÁSI MEGOLDÁSOK}

Az alkalmazandó megoldás kiválasztásához a területi adottságok, költséghatékonysági, környezetvédelmi szempontok, technológiai alternatívák együttes figyelembevétele szükséges. Ennek előnye az alacsony energiaigény, a keletkezés helyéhez közeli tisztítás és a hasznosítás, viszont hátránya az engedélyeztetés, a tulajdonviszonyok és az üzemeltetés. Azonban többfajta technológiai alternatíva létezik, például szennyvíztisztító kisberendezések, szennyvíztisztító kistelepek, természetközeli megoldások és ezek kombinációi.

Szennyvíztisztító kisberendezéseket családi házaknál, intézményeknél, lakótömböknél lehet alkalmazni, ahol a tisztított szennyvíz jellemzően elszikkasztásra kerül, az üzemeltetés egyszerü, költséghatékony, ugyanakkor engedélyeztetése nehézkes, próbaüzem szükséges.

Szennyvíztisztító kistelepeket általában nagyobb lakosegyenérték (kisebb falvak) mellett terveznek. Ilyen technológia lehet a vegyszeres kezeléssel bővített mechanikai fokozat (CEPTChemically Enhanced Primary Treatment), a granulált iszapos UASB technológia, mely a vertikálus áramú anaerob reaktor (UASB-Upflow Anaerobic Sludge Blanket), de természetesen az eleveniszapos és biofilmes technológiák is szóba jöhetnek.

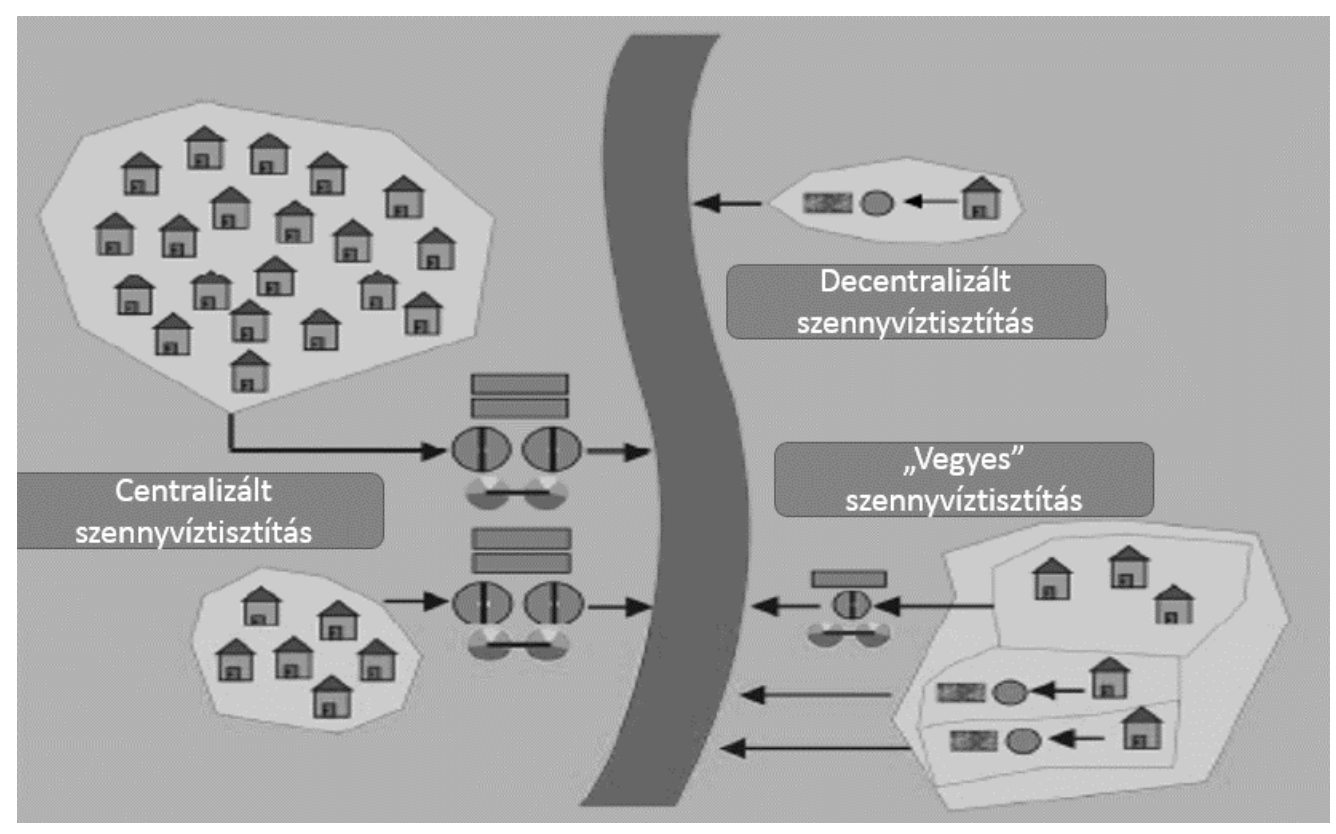

3. ábra Centralizált és decentralizált szennyvíztisztítási megoldások (szerző szerkesztése [16] alapján).

A 3. ábra vegyesen mutatja a centralizált és decentralizált megoldásokat. Az ábrából láthatjuk, hogy a hibrid megoldások is szóba jöhetnek vagyis egy agglomeráció szennyvizének zömét egy nagyobb telep kezeli, a fennmaradó rész tisztításához pedig decentralizált megoldásokat alkalmazunk.

Ez a helyzet akkor állhat fenn, ha a központi telep évtizedekkel elötti lakosszámra volt tervezve, de közben az urbanizáció hatására bővült a kiszolgálandó terület. Ekkor a kapacitás növekedésének igényét nem a központi telep vállalja fel, hanem kis kapacitású szennyvíztisztító berendezéseket létesítünk, ezzel kihagyva a már meglévő telepre befolyó hidraulikai és biológiai újraméretezést és a meglévő csatornahálózatot sem terheljük tovább.

A város közepén elhelyezett kisebb telepek esetében a müszaki szempontok mellett ki kell emelni, hogy egy szennyvízkezelő mü közelében a telkek kevesebbet érnek, a lakosság nem 
szívesen költözik annak közelébe. Ezt úgy is nevezhetjük, hogy a telep tényleges helyigényén túl van egy ún. pszichológiai lábnyoma, melynek csökkentési lehetősége a környezettudatos nevelésben és szociológiai vonatkozásaiban rejlik.

\section{ÖSSZEGZÉS}

Ha egy település vagy településrész szennyvízkezelése nem megoldott, többféle lehetőséget kell összevetni; egyrészről a csatornahálózat kiépítésével meglévő szennyvízgyüjtő- és kezelő rendszerre lehet csatlakozni, másrészről egyedi, decentralizált megoldásokat lehet keresni. A decentralizált szennyvízkezelés az esetlegesen túlterhelt csatornahálózat negatív következményeit kiküszöböli, azonban több, kisebb kapacitású telep vagy berendezés müködtetését feltételezi. A kisberendezések kialakítása több módon is lehetséges.

Kiszolgálhat akár több ingatlanból álló csoportot, valamint elhelyezése ingatlanonként lehet egyedi is, illetve ezek együttes alkalmazására is van lehetőség. Ezek után kerül sor a tisztított szennyvíz elhelyezésére, mely történhet egy felszíni befogadóba, vagy szikkasztással a talajba. A decentralizált megoldásoknál az extenzív, természetközeli eljárások is szóba jöhetnek; például a mechanikai tisztítás után a szennyvíz szikkasztható.

Ezen megoldások a 2000 lakosegyenérték alatti települések szennyvízkezelésének alternatívái lehetnek. A piacon több száz forgalmazó található, akik egyedi szennyvízkezelő rendszereket terveznek és telepítenek. Szükséges lenne összegyüjteni az adott berendezések üzemeltetési tapasztalatait az egyes alternatívák kapacitásának értékeléséhez. További lehetőség az anyagforgalmi modellezésen alapuló szimulációs rendszerek használata, mellyel a befolyó szennyvízterhelés időbeli változásának hatása is előre jelezhető, és a kutatás folytatásában a következő lépcsőt jelenti.

\section{FELHASZNÁLT IRODALOM}

[1] BEREK, T.: A vízbiztonsági tervezés szerepe a fenntartható vízgazdálkodásban; Müszaki Katonai Közlöny XXVI. 2. (2016) 32-48. o.

[2] BEREK, T.; DÉNES, K.: A Vizbázisok védelme különös tekintettel a katonai táborok vízellátására; Müszaki Katonai Közlöny XXV. 1. (2015) 122-130. o.

[3] CSÖSZ, L.: A vízminőség-védelemmel kapcsolatos problémakör hazai helyzete; Hadmérnök XIII. 1. (2018) 168-177. o.

[4] 4/1984. (II. 7.) OVH rendelkezés a szennyvízbírságról

[5] KÁRPÁTI, Á.: A szennyviztisztítás követelményei és a tisztitótelep típusválasztási lehetőségei Magyarországon; MASZESZ Hírcsatorna VI. 3. (2003) 3-11. o.

[6] 28/2004. (XII. 25.) KvVM rendelet a vízszennyezö anyagok kibocsátásaira vonatkozó határértékekröl és alkalmazásuk egyes szabályairól

[7] BENEDEK, P.; VALLÓ, S.: Viztisztitás-Szennyviztisztitás; Műszaki könyvkiadó, 1982.

[8] VERMES, L.: Vizgazdálkodás; Mezőgazdasági Szaktudás Kiadó, 1997.

[9] FÖRSTNER, U.: Környezetvédelmi technika; Springer-Verlag, 1993.

[10] BARÓTFI, I.: Környezettechnika; Mezőgazdasági Kiadó, 2003.

[11] https://www.theguardian.com/culture/2018/feb/04/fatberg-museum-london-displaypickling-age-waste (hozzáférés: 2018.10.05.)

[12] JOBBÁGY, A.; SZÁNTÓ, I.; VARGA, GY., SIMON, J.: Sewer system odour control in the Lake Balaton area; Water Science and Technology, XXX. 1. 1994, pp. 195-204. 
[13] DULOVICS, Dné.; DULOVICS, D.: Szag és korróziós problémák a csatornahálózatban, MASZESZ Hírcsatorna, VI. 3., 2004. 3-8. o.

[14] SOMODI, F.; RADÁCS, A.; KÁRPÁTI, Á.: Csatornaszag megszüntetése a szennyvíz gyüjtésénél. A szennyvíz-gyüjtés, tisztitás és iszapkezelés általános problémái; Tanulmány-gyüjtemény No. 8. Veszprémi Egyetem, Környezetmérnöki és Kémiai Technológia Tanszék, 2003, 95. o.

[15] KÁRPÁTI, Á.: A szennyviztisztítás alapjai; http://koe.hu/wpcontent/uploads/2016/07/§_szennyvíztisztítás.pdf (letöltve: 2018.10.05.)

[16] FRECHEN, F.-B.: Technische Entscheidungskriterien für dezentrale oder zentrale Abwasserreinigungsanlagen; https://www.uni-

kassel.de/fb14bau/fileadmin/datas/fb14/Institute/IWAU/Siedlungswasserwirtschaft/Vort raege/Vortraege_2014/A_DWA_O6_LR_Entscheidungskriterien_2014-11-05_P.pdf (letöltve: 2018.10.05.) 